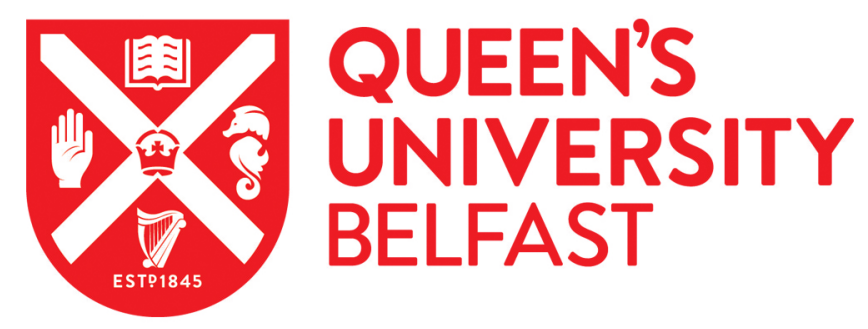

\title{
Qualitative study on the factors and role of residential staff that influence and effect the support provided to adults with intellectual disabilities regarding the expression of their sexuality
}

Brown, M. (2022). Qualitative study on the factors and role of residential staff that influence and effect the support provided to adults with intellectual disabilities regarding the expression of their sexuality. EvidenceBased Nursing. https://doi.org/10.1136/ebnurs-2021-103487

Published in:

Evidence-Based Nursing

Document Version:

Peer reviewed version

Queen's University Belfast - Research Portal:

Link to publication record in Queen's University Belfast Research Portal

\section{Publisher rights}

Copyright Author(s) (or their employer(s)) 2022. Published by BMJ

This is an open access Creative Commons Attribution-NonCommercial License (https://creativecommons.org/licenses/by-nc/4.0/), which permits use, distribution and reproduction for non-commercial purposes, provided the author and source are cited.

\section{General rights}

Copyright for the publications made accessible via the Queen's University Belfast Research Portal is retained by the author(s) and / or other copyright owners and it is a condition of accessing these publications that users recognise and abide by the legal requirements associated with these rights.

Take down policy

The Research Portal is Queen's institutional repository that provides access to Queen's research output. Every effort has been made to ensure that content in the Research Portal does not infringe any person's rights, or applicable UK laws. If you discover content in the Research Portal that you believe breaches copyright or violates any law, please contact openaccess@qub.ac.uk. 


\section{Evidence-Based Nursing}

Study type: Qualitative study

Author's declarative title: A qualitative study on the factors and role of residential staff that influence and effect the support provided to adults with intellectual disabilities regarding the expression of their sexuality.

Commentary on: Leclerc M.-J. \& Morin D. Factors affecting residential staff's role in supporting the sexuality of adults with intellectual disabilities. J Appl Res Intellect 2021. DOI:10.1111/jar.12935

\section{Commentary}

\section{Implications for practice and research}

- Future research should identify support worker's views and perceptions of the sexuality of people with intellectual disabilities

- An organisational framework to guide support workers is required to develop their knowledge and practice regarding sexuality and people with intellectual disabilities

\section{Context}

There has been growing attention on the sexuality needs and concerns of people with intellectual disabilities, set within the wider context of their fundamental right to express their sexuality ${ }^{1}$. The work of Leclerc and Morin ${ }^{2}$ highlights the important role of residential support workers in supporting people with intellectual disabilities in the expression of their sexuality. The findings accord the wider research evidence and the need to ensure that professionals have access to education and development ${ }^{1}$.

\section{Methods}

The primary aim of the study was to identify factors that enabled or inhibited support workers in residential care settings to enable people with intellectual disabilities to express their sexuality. The study adopted a qualitative design involving semi-structured interviews with a convenience sample of 12 support workers, 10 women and 2 men working in residential services for people with intellectual disabilities in Quebec, Canada. Thematic data analysis was used to identify four emergent themes.

\section{Findings}

Participants ages ranged from 24-44, with a mean of 33 years, working with people with intellectual disabilities for on average 3.5 years working in residential care settings. Four themes were identified from the data; role of support staff, experiences, policies and training. Support workers lacked access to policies to guide their practice and had limited access to education and training to facilitate the development of this aspect of their role. There are opportunities for residential support workers to develop their role in enabling people with intellectual disabilities to express their sexuality and in the promotion of sexual health and well-being. Access to education and training is required to enhance their knowledge, skills and confidence to more effectively support people with intellectual disabilities.

\section{Commentary}

This study focused on the role of residential support workers in supporting people with intellectual disabilities to express their sexuality. The findings of the study are reflective of and adds to the body of research evidence regarding that is known regarding the role of support 
workers and echo the concerns and possible ways forward. ${ }^{1,2}$ An important finding arising from the study is both the perceived and desired roles of residential support workers in enabling people with intellectual disabilities to express their sexuality in whatever form that may take. This is necessary and important as all people with intellectual disabilities are unique sexual beings with the right and a desire to express their sexuality. Yet historically there has been an assumption that people with intellectual disabilities are either asexual or hypersexual; both are incorrect. ${ }^{1}$ People with intellectual disabilities want the same opportunities to express their sexuality as those in the wider population and to experience friendships and intimacy. Some will require support to enable this expression to be a reality.

Residential support workers play key roles in the lives of many people with intellectual disabilities who require access to care and support to be independent. Some people with intellectual disabilities need support to explore, discuss and express their sexuality and this is an important role for residential support workers. ${ }^{2,3}$ However, many residential support workers feel poorly prepared to undertake this critical element of their role, lacking access to organisational policies and procedures that sets out the scope of this element of their practice. 1,2,3 Another significant issue that needs to be addressed is access to education and practice development that grows the knowledge, skills and confidence of residential support workers to fulfil this element of their role.

\section{References}

1. Brown M, McCann E. The views and experiences of families and direct care support workers regarding the expression of sexuality by adults with intellectual disabilities: A narrative review of the international research evidence. Res Dev Disab, 2019; 1(90), 80-91.

2. Deffew A, Coughlan B, Burke T. et al. Staff member's views and attitudes to supporting people with an Intellectual Disability: A multi-method investigation of intimate relationships and sexuality. $J$ Appl Res Intellect, 2021. DOI.org/10.1111/jar.12897

3. Medina-Rico, M., López-Ramos, H. and Quiñonez, A., 2018. Sexuality in people with intellectual disability: Review of literature. Sexual and Disab, 2018; 36(3), 231-248.

4. Leclerc M.-J. \& Morin D. Factors affecting residential staff's role in supporting the sexuality of adults with intellectual disabilities. J Appl Res Intellect 2021. DOI:10.1111/jar.12935

\section{Commentator details}

Name: Professor Michael Brown

Affiliation: Queen's University Belfast, School of Nursing \& Midwifery

Corresponding address: 97 Lisburn Road, Belfast, Northern Ireland, BT9 7BL

Email:m.j.brown@qub.ac.uk

\section{Competing interests}

No competing interested declared 